\title{
Cytotoxic Activities of Phytochemical Components from Ethanol Extract of Ajwa Date on Human Hepatoma Cancer Cells in Vitro
}

\author{
Faizah Ahmed AlMalki*
}

\section{Faizah Ahmed AlMalki*}

Department of Biology, College of Science, Taif University, P.O. Box 11099, Taif 21944, SAUDI ARABIA.

\section{Correspondence}

\section{Faizah Ahmed AIMalki}

Department of Biology, College of Science, Taif University, P.O. Box 11099, Taif 21944 SAUDI ARABIA.

E-mail/ fa.ahmad@tu.edu.sa

History

- Submission Date: 23-09-2021;

- Review completed: 12-10-2021;

- Accepted Date: 21-10-2021.

DOI : 10.5530/pj.2021.13.214

Article Available online

http://www.phcogj.com/v13/i6

\section{Copyright}

(C) 2021 Phcogj.Com. This is an openaccess article distributed under the terms of the Creative Commons Attribution 4.0 International license.

\begin{abstract}
Background: Hepatocellular carcinoma $(\mathrm{HCC})$ is a primary liver cancer that occurs and develops in the liver and is among the top frequent cancer-related death worldwide. Currently, clinical treatment options can control the HCC cancer, but, in some cases, it develops resistance to standard therapies and does not respond to these treatment options. Date palm (Phoenix dactylifera $L$.) is used in traditional and alternative therapies for its various health benefits. Objective: The present study aims to evaluate the anticancer and cytotoxic effects of Ajwa date ethanol extract (ADX) on hepatocarcinoma (HepG2) cells. Materials and Methods: The polyphenolic constituents of ADX were analysed using HPLC to identify the major polyphenols in the extract. The cell proliferation and viability percentages were examined through Trypan blue dye and MTT assay. Additionally, DNA fragmentation and mRNA expression level of apoptotic genes were applied to investigate the cell death mechanism. Results: The ADX induced significant cytotoxic effects against hepatocarcinoma cells in vitro. It was reduced the viability and proliferation in HepG2 cells treated with $\mathrm{ADX}$ at various concentrations for different exposure times comparing to untreated cells. Furthermore, the microscopic investigation showed apparent changes in HepG2 treated cells and the results of DNA fragmentation showed an increase in the percentage of fragmented DNA. Moreover, the expression of $p 53$ and Bax genes was up regulated, while $B \mathrm{Cl}-2$ gene expression was down regulated, in HepG2 cells treated with ADX. Conclusion: The ADX may be a promising natural anticancer agent and can be developed as a new anticancer therapy tool.
\end{abstract}

Key words: Anticancer, Date extract, DNA fragmentation, HepG2 cells, MTT assay.

\section{INTRODUCTION}

Hepatocellular carcinoma (HCC) is considered one of the leading causes of mortality and is among the top frequent cancer-related death worldwide. Its incidence has increased over the last several decades, and experts believe that cases of HCC will continue to grow until 2030 worldwide. ${ }^{1-2}$ HCC is the leading liver cancer originating from hepatocytes, occurring in more than $80 \%$ of liver cancer cases. ${ }^{3-4}$ It is well known to be caused by chronic liver diseases, such as chronic hepatitis B and $\mathrm{C}$, alcohol addiction, cigarette smoking, and dietary contaminants like aflatoxins. ${ }^{5-6}$ Several studies have shown that the hepatitis $\mathrm{C}$ virus (HCV) aggravates hepatocytes' transformation into malignant cells via various routes. ${ }^{7}$ In addition, many aflatoxins found on grains, peanuts, soybeans, and maize are correlated with the development of HCC. ${ }^{8}$ The HCC disease is currently controlled via clinical therapeutic methods, including liver transplantation, transarterial chemotherapy, radiotherapy, and systemic therapy targeting multiple receptor tyrosine kinases using low molecules weight. ${ }^{9}$ However, treatment selection depends on the characteristics of the tumor, the existence of the underlying liver disease, age, other medical comorbidities, and available medical resources and local expertise. ${ }^{5}$ Unfortunately, each method presents several issues, such as drug resistance and adverse side effects. Therefore, the search for alternative products for cure with more minor or free toxic effects on normal tissues and cells continues.
Plants products have been used to treat several cancers since they have an anticancer effect against various forms of this disease. ${ }^{10}$ These natural products have multiple action mechanisms, including cell growth inhibition, cell differentiation variance, and apoptosis initiation. ${ }^{11}$ Various natural products, such as sulfated polysaccharides, isoverbascosides, camptothecin, tachyplesin, matrine, tylophorin, and 7-OH-4-CH(3)-coumarin, are known to have differentiation-inducing potential for hepatocellular carcinoma. ${ }^{12}$ Many plant-derived phenolic compounds such as flavonoids are potent antioxidants with reported anti-carcinogenic effects. ${ }^{13}$ In addition, many flavonoids and phenols play an essential role in cancer therapy by controlling genetic pathways without side effects. ${ }^{14-15}$ Thus, researchers have sought to develop plant-derived anticancer agents promising cancer prevention and treatment activities in vitro. ${ }^{16}$

The date palm tree (Phoenix dactylifera L.) is an essential plant in many countries, particularly in the Middle East, North Africa, South Europe, South America, Pakistan, and India. ${ }^{17}$ Date fruit is a natural source of antioxidants and compounds that are antimutagenic. It contains significant quantities of amino acids, vitamins such as $\mathrm{C}, \mathrm{B} 1, \mathrm{~B} 2$, and $\mathrm{A}$, and nicotinic acid. ${ }^{18-20}$ Ajwa is a common date fruit grown only in Al-Madinah Al-Monwarah in the Kingdom of Saudi Arabia (KSA) has many benefits and is a rich source of potassium, iron, and natural fibers. ${ }^{21-22}$ Previous studies confirmed the numerous protective and clinical properties of Ajwa date, including antioxidant, anti-inflammatory, nephroprotective, and hepatoprotective activities. ${ }^{23-26}$ that stem from 
the numerous chemical compounds found in the fruit. Flavonoids, glycosides, phytosterols, and polyphenols are the most abundant phytochemicals in the Ajwa date. ${ }^{24}$ It has been found that ethanolic extracts (90\%) of Ajwa date (ADX) have the highest amount of total phenolic and flavonoid contents and more potent antioxidant properties than two different types (Aseel and Zaid) of local Pakistani dates. ${ }^{27}$ Anticancer properties of Ajwa could effectively inhibit the growth of cancer cells in vitro such as Caco-2 \& HCT-116 colon, ${ }^{28-29}$ human MCF-7 breast cancer, ${ }^{30-29}$ and HepG2 cell line, ${ }^{29}$ and in vivo like sarcoma-180 cells in mice. ${ }^{31}$ ADX has shown significant beneficial effects against HCC induced by diethylnitrosamine in a rat model; in this study, the treated rats developed a typical liver architecture and showed reductions in liver enzymes and increases in antioxidant enzymes. ${ }^{32}$ Ethyl acetate extracts of Ajwa date may cause cell cycle arrest and reduce PC3 prostate cancer cells. ${ }^{33}$ The effect of the ajwa date pulp (ADP) extract was recently associated with reactive oxygen species (ROS) generation and depletion of the mitochondrial membrane's capacity in cancer cells. Also, ADP extract induced DNA damage in HCC cells leading to cell cycle arrest at stages $S$ and G2/M, followed by apoptosis via a TP53-independent pathway. ${ }^{34}$ Besides, Ajwa nano preparation has protective effects against doxorubicin-induced cardiac disorders and can increase the antioxidant of heart tissues. ${ }^{35}$ The current study investigated the anticancer effect of ethanolic ADX on HepG2 cancer cells by evaluating cell viability and proliferation, as well as the DNA damage and changes in the treated cells morphology were examined. Therefore, the present study findings make substantial contributions to cancer therapeutics based on natural products.

\section{MATERIAL AND METHODS}

\section{Ajwa date extract preparation}

Fresh Ajwa dates were brought from a local market in Taif Province, Kingdom of Saudi Arabia. First, the dates were washed twice with double distilled water, and their pith was separated manually. Next, the pulp was dried, crushed, and then extracted with ethanol at a ratio of 1:3 (w/v) at $24{ }^{\circ} \mathrm{C}$ for $48 \mathrm{~h}$. Next, the extract was passed through the Whatman filter and Millipore filter. Finally, the prepared extract was condensed and stored at $-80^{\circ} \mathrm{C}$ before use to produce a viscous syrup.

\section{HPLC analysis for ADX}

HPLC analysis was performed in ADX to determine its polyphenolic contents; Agilent 1260 Series. The separation of the extract was performed on a column of C18 (LI.D. $4.6 \mathrm{~mm} \times 250 \mathrm{~mm}, 5 \mu \mathrm{m}$ particle size). Water (A) and 0.02 percent trifluoroacetic acid in acetonitrile (B), with a mean flow rate of $1 \mathrm{ml} / \mathrm{min}$, were the mobile phases. The lineargradient (A) was programmed as follow: $0 \mathrm{~min}(80 \%)$; $0-5 \mathrm{~min}(80 \%)$; 5-8 $\min (40 \%) ; 8-12 \min (50 \%) ; 12-14 \min (80 \%)$. Exactly $10 \mu \mathrm{l}$ of the sample solution was injected, and the absorbance was monitored at $280 \mathrm{~nm}$ by a multiwavelength detector. The temperature of the column was set at $36^{\circ} \mathrm{C}$, and triplicate analysis was conducted. In order to get real-time chromatograms of the normal and ADX, HPLC spectra were monitored at $254 \mathrm{~nm}$.

\section{Cell line and maintenance of cell culture}

The HepG2 cells used in this study were purchased from American Type Culture Collection (ATCC) and were maintained in complete media (DMEM supplemented with $10 \% \mathrm{FBS}+1 \%$ penicillin-streptomycin) at 37 ${ }^{\circ} \mathrm{C}$ in a $\mathrm{CO}_{2}$ incubator $\left(5 \% \mathrm{CO}_{2}+95 \%\right.$ air and $100 \%$ relative humidity).

\section{In vitro cell viability/ cytotoxicity studies}

\section{Trypan blue dye exclusion assay}

Trypan blue dye exclusion assay was performed to evaluate the effects of ADX on the viability of HepG2 cancer cells. The dye is a vital stain that is not absorbed by healthy, viable cells. However, trypan blue can enter cells when damaged or dead, thereby allowing for the counting of killed cells. Viable cells have a translucent cytoplasm, with dead cells dyed blue. Briefly, $50 \mu \mathrm{l}$ of freshly prepared trypan blue solution $(0.05 \%$ distilled water) was combined for 5 minutes with $50 \mu \mathrm{l}$ cell suspension. The mixtures were then spread onto the hemocytometer slide. Cytotoxicity was monitored by counting viable cells using a light microscope; viable cells will appear with clear, uncolored cytoplasm while the dead cells will present with blue cytoplasm. ${ }^{36}$

\section{MTT assay}

Cytotoxicity of ADX was determined in vitro using the 3-(4,5-dimethylthiazol-2-yl)2,5-diphenyltetrazolium (MTT) test according to the adapted technique of Horiuchi et al. ${ }^{37}$ In this assay, MTT salt will convert to purple formazan crystals by viable, active cells. In short, cells were seeded at $1 \times 10^{6}$ cells per $100 \mu \mathrm{l}$ in 96 well plate and incubated at $37^{\circ} \mathrm{C}$ for 24 hours. Cells were treated with different $\operatorname{ADX}$ concentrations $(5,10,20$ or $40 \mathrm{mg} / \mathrm{ml})$. At $37^{\circ} \mathrm{C}$, the plates were incubated with $5 \% \mathrm{CO}_{2}$ for another 24 and $48 \mathrm{~h}$. A volume of $10 \mu \mathrm{l}$ of MTT solution was added to each well and incubated at a humidified atmosphere $\left(37^{\circ} \mathrm{C} \& 5 \% \mathrm{CO}_{2}\right)$ for 3-4 h. DMEM without addition was used as negative power. The optical density (OD) of each well was recorded at $570 \mathrm{~nm}$ wavelength. Each ADX concentration was tripled, and cell viability percentage was determined using the following equation:

Cell viability $(\%)=\frac{\mathrm{OD} \text { of Control }-\mathrm{OD} \text { of ADX treatment } \times 100}{\mathrm{OD} \text { of Control }}$

\section{Apoptosis detection via DNA fragmentation assay}

DNA fragmentation is used as a biochemical marker to measure apoptosis. ${ }^{38}$ In this study, the DNA content of HepG2 treated cells was degraded by nucleases activated via the caspase pathway. A DNA fragmentation assay was carried out using agarose gel electrophoresis. According to the manufacturer's instructions, following ADX treatment, DNA fragmentation induced in the treated cells was determined by a Quick Apoptotic DNA Ladder Detection Kit (BioVision, USA). The DNA pellet was obtained from $1 \otimes 10^{6}$ harvested cells for the control and treated cells and was dissolved in $30 \mu \mathrm{l}$ suspension buffer and electrophoresed in $2 \%$ agarose gel containing $0.5 \mu \mathrm{g} / \mathrm{ml}$ ethidium bromide for $1-2 \mathrm{~h}$. The fragmented DNA bands were visualized by a UV light transilluminator and photographed. The percentages of fragmented DNA were evaluated colorimetrically at 575 nm using Diphenylamine (DPA) as defined by Burton ${ }^{39}$ and updated by Perandones et al..$^{40}$ The DPA assay is valuable method for measuring apoptosis by determining the percentage of fragmentation of DNA into the oligosomal-sized fragment. The principle of DPA assay is based on the interaction between the DNA backbone sugar (deoxyribose) with DPA in the acidic environment producing a bluish-green color that can be detected by a wavelength ranging from 560-595 $\mathrm{nm}$.

\section{Gene expression levels}

Apoptosis or programmed cell death is a tightly regulated process that is controlled via multi genes and pathways. Experimentally, apoptosis can be detected through analysis of its associated genes using cell RNA content. Briefly, total RNA was isolated using TRIzol reagent, and its purity was examined by gel electrophoresis. The RNA extracted from the control and treated cells were exposed to DNase and then used for RT-PCR to synthesize the first-strand cDNA using a reverse transcription kit (Maxime RT PreMix kit, South Korea). PCR amplification was applied in a thermal cycler (PXE 0.5 Thermo) using the primer pairs listed in Table 1 obtained from previously 
published work..$^{41-42}$ The product was run on $1.5 \%$ agarose gel and visualized by a UV transilluminator. The band signal intensities were quantified using Gel-Pro software (version 3.1 for Windows 3) after scanning. The target gene-amplification product level ratio to that of the glyceraldehyde 3-phosphate dehydrogenase (GAPDH) gene was calculated to normalize the initial variation in sample concentration as a control for reaction efficiency. ${ }^{43-44}$

\section{Statistical Analysis}

Using SPSS 11.0 software, statistical analysis was performed. A one-way ANOVA assessed significant differences between treatment groups, followed by Duncan tests. ${ }^{45-46}$ The outcomes are expressed in the mean \pm SE. Differences were considered significant at $\mathrm{P}<0.05$.

\section{RESULTS AND DISCUSSION}

The polyphenolic constituents of ADX were investigated, and HPLC analysis revealed the occurrence of six primary polyphenols, including gallic acid (GA), naringenin (NG), catechin, chlorogenic acid, caffeic acid, and syringic acid at concentrations of $28.41 \pm 1.62,16.96 \pm 1.3$, $4.91 \pm 0.75,2.40 \pm 0.38,1.17 \pm 0.18$, and $1.17 \pm 0.12 \mathrm{mg} / \mathrm{g}$, respectively (Figures 1-2). The concentration of GA was 1.75-fold more significant than that of NG, and this compound made up approximately half $(28.41 \mathrm{mg} / \mathrm{g})$ of the total polyphenolic components $(56.31 \mathrm{mg} / \mathrm{g})$ of ADX. A previous investigation ${ }^{29}$ demonstrated the presence of gallic, syringic, and coumaric acids as the primary phenolic contents in the aqueous extract of Ajwa date, which confirms our results. Nematallah et al. ${ }^{47}$ examined various extraction solvents and methods to get the highest amount of polyphenols and flavonoids from Ajwa date fruit, and they reported that aqueous acetone (50\%) extract is the best one.
GA and its analogs have several biological activities, including antioxidant, antimutagenic, and anticarcinogenic. It prevents proliferation and causes apoptosis in the lymphoblastic leukemia C121cell line. ${ }^{48}$ It has also been reported that GA with other cancer drugs showed a promising anticancerous effect. In the Paclitaxel/GA combination, the highest cytotoxic effect, induction of apoptosis, and a substantial elevation in P53 and Caspase 3 levels were observed in Hela cervical cancerous cells. ${ }^{49}$ Epidemiological studies have revealed that GA and NG compounds exert anticancer, antiproliferative, and pro-apoptotic activities against different cancer cells. ${ }^{50-51}$ Phenolic compounds are generally accepted to possess a broad spectrum of health-beneficial effects. ${ }^{52-54}$ It is also reported that, in vivo, using mouse model, Ajwa bioactive ingredients were safe from body weight loss caused by chemotherapeutic agent doxorubicin (DOX) which is used clinically for breast cancer treatment. ${ }^{55}$

The six primary polyphenols were detected, including gallic acid, naringenin, catechin, chlorogenic acid, caffeic acid, and syringic acid.

The cytotoxic effect and the most significant concentration of ADX against HepG2 cells $\left(\mathrm{IC}_{50}\right)$ were investigated experimentally using different extract concentrations and treatment times. The screening results using Trypan blue staining are presented in Table 2 and Figure $3 \mathrm{~A}$. The data showed that $20 \mathrm{mg} / \mathrm{ml} \mathrm{ADX}$, referred to as the $\mathrm{IC}_{50}$ value, could strongly inhibit HepG2 cell proliferation by $48 \%$ and $60 \%$ after treatment for 48 and $72 \mathrm{~h}$, respectively. The most extensive inhibitory effect on cells proliferation was obtained at $40 \mathrm{mg} / \mathrm{ml}$; this concentration inhibited cell proliferation by $60 \%$ and $75 \%$ after treatment for 48 and $72 \mathrm{~h}$, respectively (Figure $3 \mathrm{~A}$ ). Our findings are in agreement with Khan et al. ${ }^{30}$ data. They calculated the $\mathrm{IC}_{50}$ value of MCF-7 breast cancer cells exposed to different concentrations of MEAD for $48 \mathrm{~h}$, as $18.2 \mathrm{mg} /$

Table 1: Summarized the targeted primers sequences used in the study.

\begin{tabular}{lll}
\hline Genes & Forward Primer & Reverse Primer \\
\hline Bax & 5'-CCTGTGCACCAAGGTGCCGGAACT-3' & 5'-CCACCCTGGTCTTGGATCCAGCCC-3' \\
P53 & 5'-TGCGTGTGGAGTATTTGGATG-3' & 5'-TGGTACAGTCAGAGCCAACCTC-3' \\
BCl2 & 5'-TTGTGGCCTTCTTTGAGTTCGGTG-3' & 5'-GGTGCCGGTTCAGGTACTCAGTCA-3' \\
GAPDH & 5'-ATGGCACCGTCAAGGCTGAG-3' & 5'-GCAGTGATGGCATGGACTGT-3'
\end{tabular}

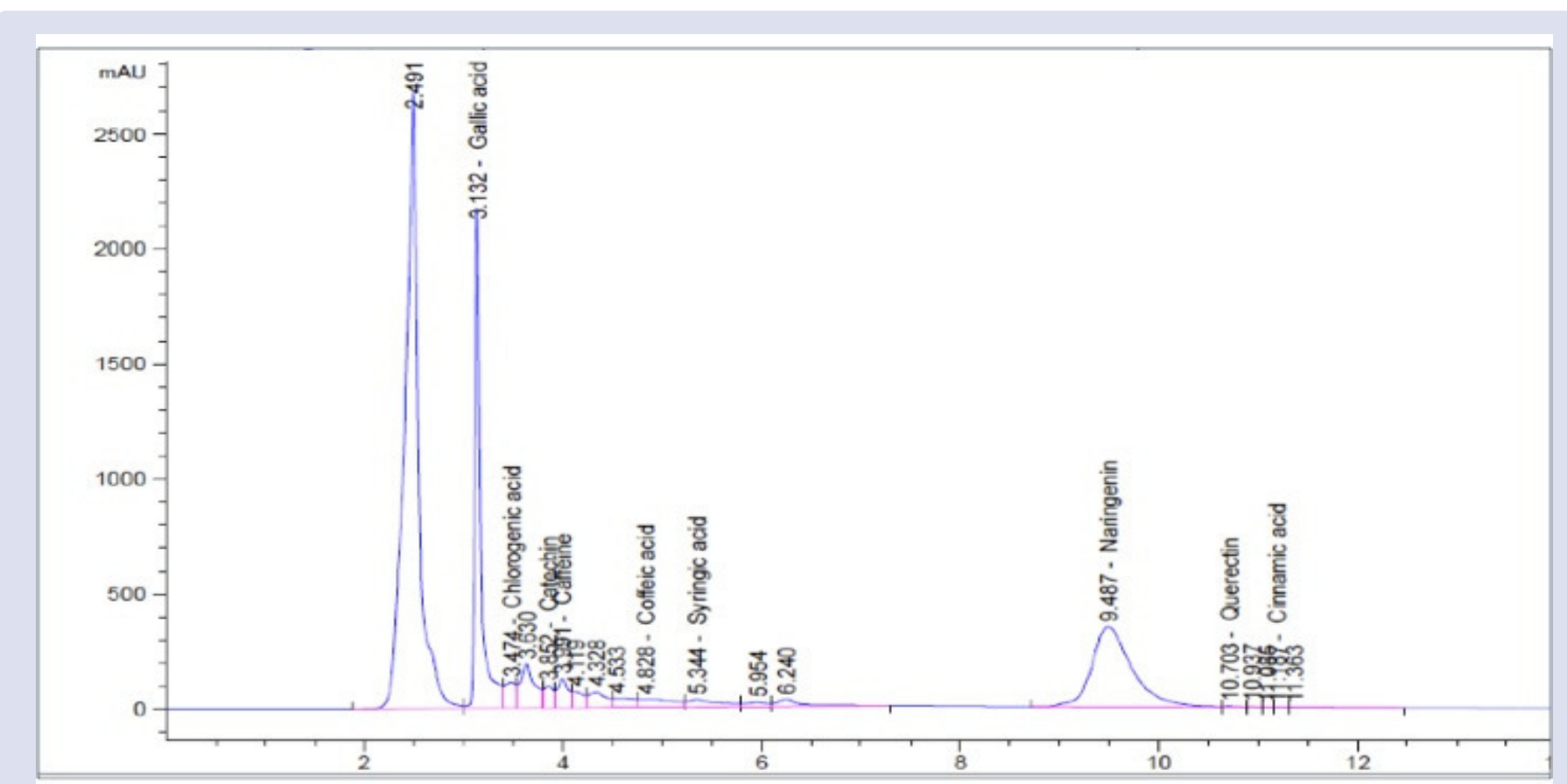

Figure 1: HPLC chromatogram of Ajwa date extract (ADX). It represents the different polyphenolic contents in ADX. 


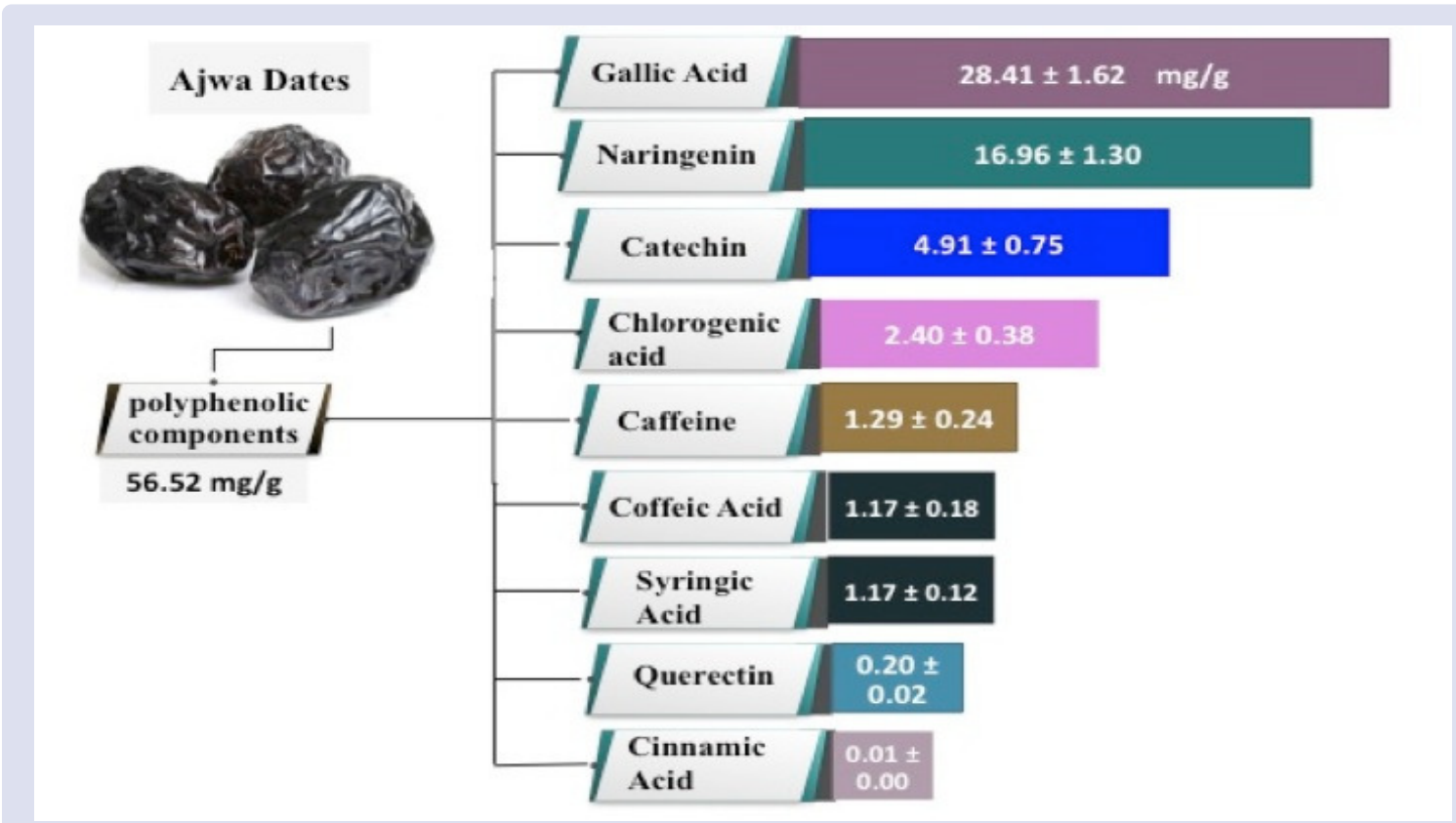

Figure 2: Diagram shows the different constituents of polyphenolic components in ADX, present as mg/g.

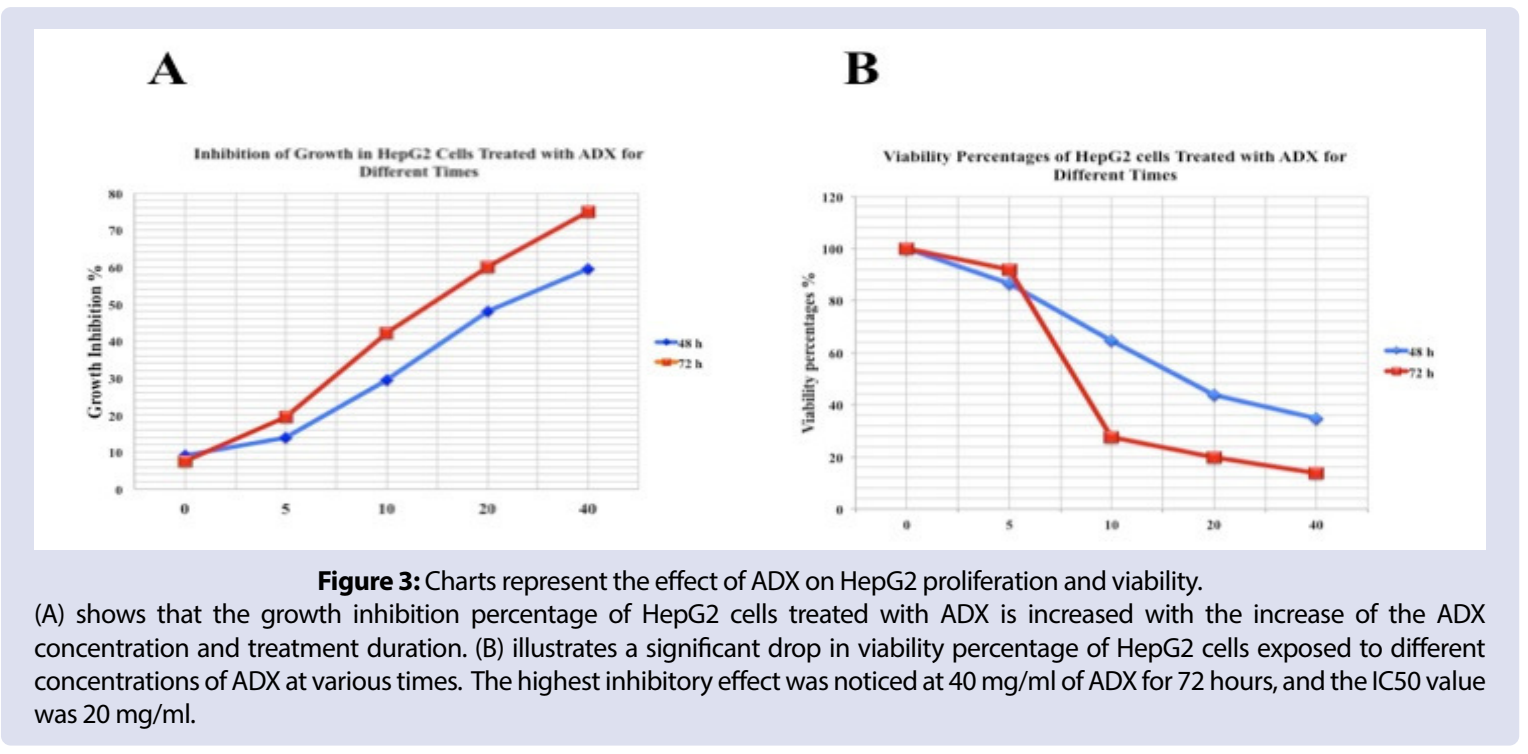

Table 2: Illustrates $I_{50}$ of ADX and its effect on HepG2 cancer cells' proliferative percentage at different exposure times.

\begin{tabular}{ccc|}
\hline \multirow{2}{*}{ Doses of ADX $(\mathrm{mg} / \mathrm{ml})$} & Proliferative Percentage of HepG2 cells at different exposure times \\
\cline { 2 - 3 } & $48 \mathrm{~h}$ & $72 \mathrm{~h}$ \\
5 & $90.9 \pm 1.50^{\mathrm{a}}$ & $92.5 \pm 1.70^{\mathrm{a}}$ \\
10 & $86.0 \pm 1.0^{\mathrm{a}}$ & $80.5 \pm 1.85^{\mathrm{b}}$ \\
20 & $70.5 \pm 2.44^{\mathrm{b}}$ & $57.8 \pm 2.65^{\mathrm{c}}$ \\
40 & $52.0 \pm 2.25^{\mathrm{c}}$ & $40.0 \pm 1.90^{\mathrm{d}}$ \\
& $40.5 \pm 2.75^{\mathrm{d}}$ & $25.0 \pm 0.87^{\mathrm{e}}$ \\
\hline
\end{tabular}

ml. Moreover, Siddiqui et al. ${ }^{34}$ reported the $\mathrm{IC}_{50}$ values for ethanolic Ajwa date pulp extract (ADP) as 20.03 and $16.78 \mathrm{mg} / \mathrm{ml}$ after treating HepG2 cells for 24 and $48 \mathrm{~h}$, respectively.

In addition, the viability of HepG2 cancer cells after being exposed to different concentrations of ADX was analyzed using the MTT assay, and the collected data showed a dramatic decrease in the cell viability comparing to the untreated control cells (Figure 3B).
Means with different superscripts (a, b, c, d, and e) in the same column vary significantly at $\mathrm{P}<0.05$. Cell numbers are counted, data expressed as a percentage of untreated power.

Previous studies have proposed that some constituents of ADX, such as NG and GA, could reduce cancer cell proliferation by arresting the cell cycle ${ }^{28}$ and inducing apoptosis in a time- and dose-dependent manner. ${ }^{56} \mathrm{NG}$ has cytotoxic, genotoxic, and apoptotic activities by 
developing reactive oxygen species (ROS) on cancer cells. Thus, the derived NG compound could also be used as an antiproliferative agent to treat cancer. ${ }^{57}$ Our results follow previous studies, which showed that GA is involved in the regulation of $p 53$, which controls the cell cycle and has been implicated in tumor suppression. ${ }^{58}$ Interestingly, these two compounds (GA \& NG) have been determined to inhibit different cancer cells include MCF7 (breast) and CACO (intestinal) cell lines. ${ }^{59-60}$ In addition, Al-Radadi ${ }^{29}$ reported that aqueous Ajwa extract could be used in the biosynthesis of platinum nanoparticles and effectively reduced up to $73 \%$ of the growth of the HepG2 cells in vitro. Likewise, Siddiqi et al. ${ }^{34}$ findings demonstrated a significant decrease in viability of human liver HepG2 cancer cells treated with ADP, and this action is time- and dose-dependent.

The differences between treated and untreated cells were checked morphologically using Phase-contrast microscopy to investigate the impact of ADX on the HepG2 cancer cell morphology. The images of untreated HepG2 cells showed a monolayer's characteristic epithelial nature and prolific growth. Ovoid cells with clear cytoplasm and a large central nucleus have one or fragmented nuclei (Figure 4A). This type of cell with fragmented nuclei occurs physiologically in hepatocytes and is usually present in cancer cells known as binucleated cells. By comparison, ADX-treated cells with $\mathrm{IC}_{50}$ dose $(20 \mathrm{mg} / \mathrm{ml})$ for $48 \mathrm{~h}$, displayed mild to moderate decreases in the number of cells as present in Figure 4B. In addition, cells appeared shrinkage with condensed cytoplasm, membrane destruction, round shape, and cellular detachment. (Figure 4C). These morphological changes represent the initial features of apoptotic cell death. ${ }^{61}$ Moreover, significant inhibition in the cell numbers and cellular crowding was noticed after $72 \mathrm{~h}$, (Figure 4D). Similar to the present findings, Khan et al., ${ }^{30}$ Ishurd et al., ${ }^{31}$ and Siddiqui et al. ${ }^{34}$ indicated that date extracts could induce cellular changes, including blebbing of the membrane, DNA fragmentation, and cell adherence loss, leading to apoptosis and cell death. These results support our morphological findings and further validate HepG2 cell apoptosis from ADX therapy.

DNA fragmentation is a degradation of a nuclear genome in specific sites between nucleosomes. It considers a hallmark indicator for apoptosis events in cells and tissues and can be evaluated colorimetrically or via agarose gel electrophoresis. Herein, DNA fragmentation analysis further investigated the major apoptotic events in HepG2 cells treated with ADX. The percentages of fragmented DNA were calculated, and the results were listed in Table 3 and Figure 5. DNA fragments were observed colorimetrically by DPA (Table 3 ), and DNA profiles were compared via agarose gel electrophoresis (Figure 5). In ADX-treated cells, fragmented DNA increased significantly compared to untreated cells in a dose-dependent manner (Table 3 and Figure 5). Khan et al. ${ }^{30}$ showed that methanolic extract of Ajwa date (MEAD) induced apoptosis in a human MCF-7 cell line in vitro, and a reduction in living cells number was noticed while the percentage of early- or late-stage of apoptotic cells were increased. Another study ${ }^{34}$ investigated the impact of ethanolic extract of Ajwa date pulp (ADP) against HepG2 cancer cells and found that the extract induced apoptosis and DNA fragmentation in treated cells in a dose-dependent manner. The current study findings are consistent with the results of the previous investigations.

Means with different superscripts (a, b, c, and d) between groups in the same column are significantly different at $\mathrm{P}<0.05$.

Table 3: Effect of ADX treatment on the DNA fragmentation percentage induced in HepG2 cells after $48 \mathrm{~h}$.

\begin{tabular}{ccc}
\hline Treatment & \multicolumn{2}{c}{ DNA Fragmentation \% } \\
\cline { 2 - 3 } & Mean \pm SE & 0 \\
\hline Untreated Cells & $5.80 \pm 1.08^{\mathrm{d}}$ & +12.45 \\
$10 \mathrm{mg} / \mathrm{ml}$ ADX & $18.25 \pm 1.31^{\mathrm{c}}$ & +32.2 \\
$20 \mathrm{mg} / \mathrm{ml} \mathrm{ADX}$ & $38.00 \pm 2.5^{\mathrm{b}}$ & +52.20 \\
$40 \mathrm{mg} / \mathrm{ml} \mathrm{ADX}$ & $58.0 \pm 1.93^{\mathrm{a}}$ &
\end{tabular}

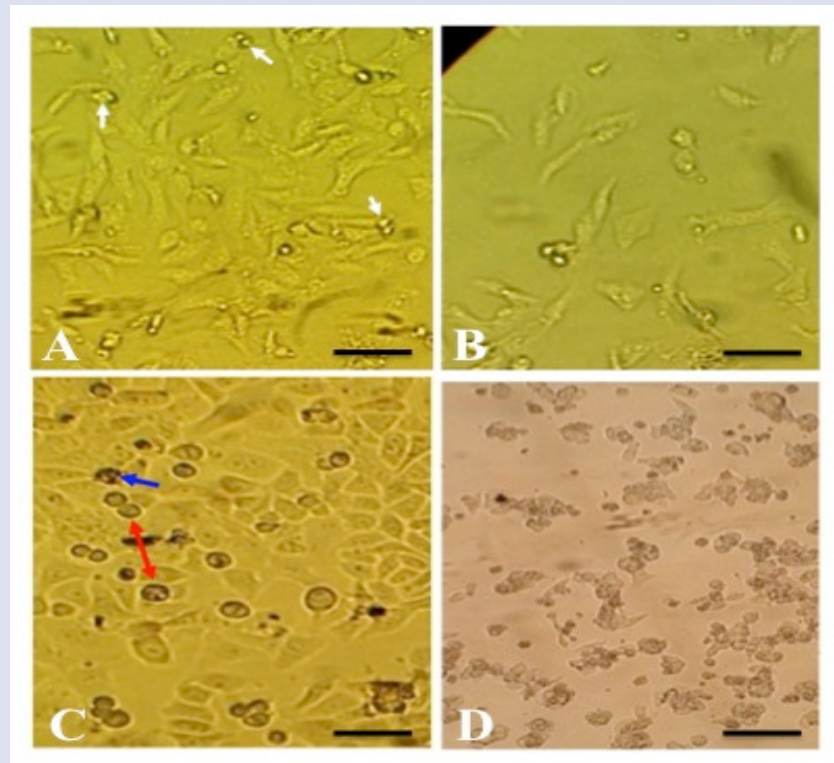

Figure 4: Inverted microscopic photographs of HepG2 Cells.

The images show untreated cells $(A)$ that appeared in monolayer and epithelial nature with fragmented nuclei indicated by white arrows. Treated with ADX at $20 \mathrm{mg} / \mathrm{ml}$ (B) and $40 \mathrm{mg} / \mathrm{ml}$ (C) after $48 \mathrm{~h}$. Arrows suggest morphologically apoptotic changes, including condensed and fragmented nuclei (red) and apoptotic bodies (blue). There were also gross decreases in cell numbers (D) with increased exposure time, $72 \mathrm{~h}$. (Magnification 200X). 
A

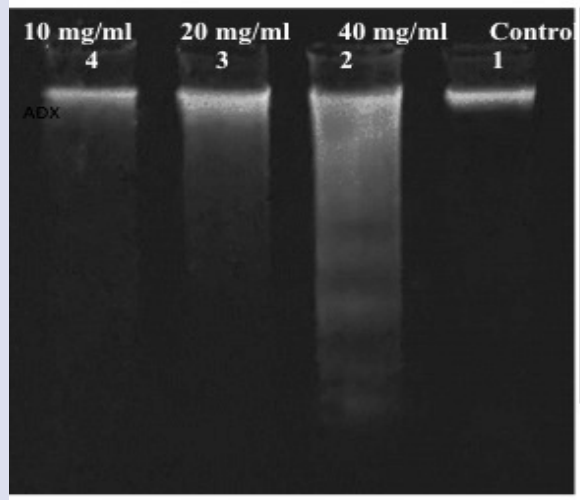

B

\section{DNA Fragmentation \%}

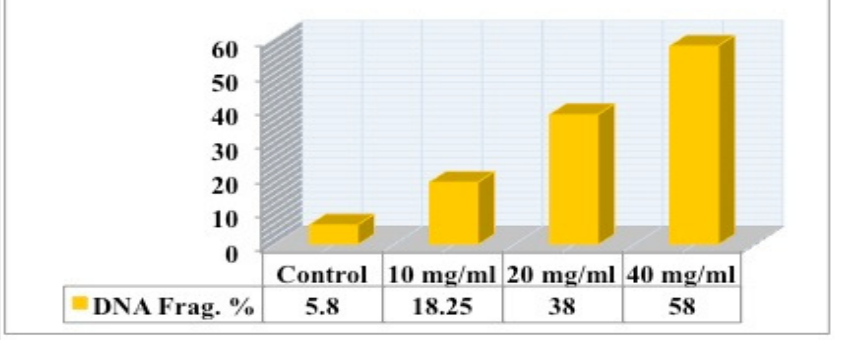

Figure 5: DNA fragmentation induced in HepG2 cells treated with ADX at the indicated doses (10, 20 and $40 \mathrm{mg} / \mathrm{ml})$ for $48 \mathrm{~h}$.

(A) showing DNA profile on $2 \%$ Agarose gel electrophoresis, $1 \times 10^{6}$ cells were used, and $20 \mu$ of DNA sample was loaded in each well. Lane 1: Control untreated cells with nonfragmented DNA. The DNA appears at the top of the gel as a high-molecular-weight band. Lane 2: Effect of 40 mg/ml ADX, Lane 3: Effect of $20 \mathrm{mg} / \mathrm{ml} \mathrm{ADX}$, and Lane 4: Effect of $10 \mathrm{mg} / \mathrm{ml} \mathrm{ADX.} \mathrm{The} \mathrm{damaged} \mathrm{DNA} \mathrm{presents} \mathrm{as} \mathrm{smmer} \mathrm{in} \mathrm{treated} \mathrm{cancer} \mathrm{cells,} \mathrm{and} \mathrm{the} \mathrm{fragmented} \mathrm{DNA}$ density increased by the increasing of ADX doses as shown in Lane 2, 3 and 4. (B) A histogram illustrates the cytotoxic effect of ADX on the DNA fragmentation percentage of HepG2 cells in comparison to the control. Data were obtained from three independent experiments and expressed as Mean \pm SEM.

\section{B}
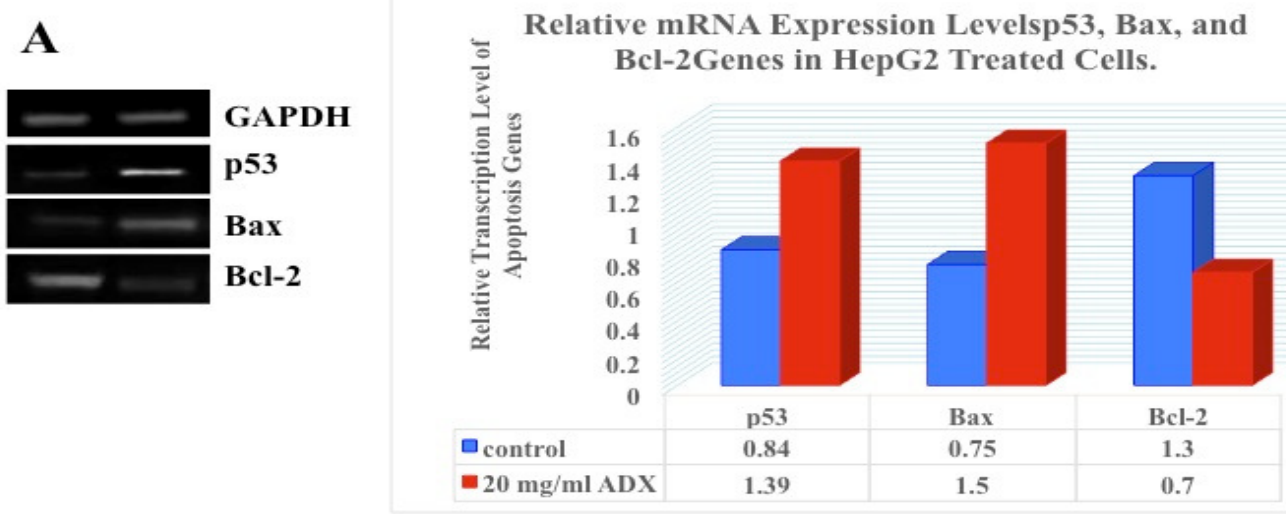

Figure 6: Shows the effects of $20 \mathrm{mg} / \mathrm{ml} \mathrm{ADX}$ treatment in pro-apoptotic and anti-apoptotic gene expression levels.

(A) 1.5\% agarose gel electrophoresis photographs illustrate the relative transcription levels of $P 53, B a x$, and $B C L-2$ genes comparing to the GAPDH gene in HepG2 treated cells for $48 \mathrm{~h}$. (B) the histogram shows an increase in Bax and p53gene expression levels by over 2-and 1.5-fold, respectively, compared with the control when cells were treated with $20 \mathrm{mg} / \mathrm{ml} \mathrm{ADX.} \mathrm{A} \mathrm{significant} \mathrm{drop} \mathrm{in} \mathrm{Bcl-2} \mathrm{expression} \mathrm{by} 2$-fold can be observed in comparison to the control. Results were obtained from three independent experiments and expressed as Mean \pm SEM.

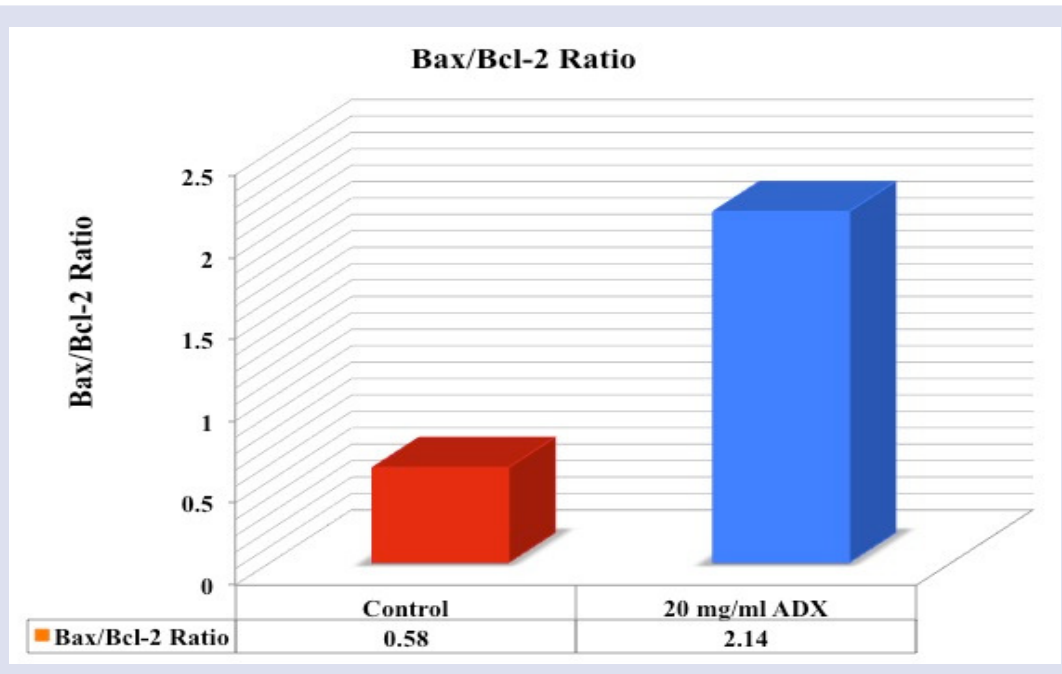

Figure 7: Histogram showing the effects of $20 \mathrm{mg} / \mathrm{ml}$ ADX treatment on Bax/Bcl-2 transcription ratio in HepG 2 treated cells for $48 \mathrm{~h}$. 
Numerous genes are involved in apoptosis process direction and/or regulation, some of them still under investigation or even undiscovered. B-cell lymphoma 2 gene (Bcl2) anti-apoptotic, BCL2-associated X protein $(B a x)$ pro-apoptotic, and tumor suppressor gene $p 53$ are critical players in cancer generation and growth. The expression levels of apoptotic genes ( $\mathrm{Bcl}-2, \mathrm{Bax}$, and $\mathrm{p53}$ ) of HepG2 cancer cells exposed to $\mathrm{ADX}$ at $\mathrm{IC}_{50}$ value $(20 \mathrm{mg} / \mathrm{ml})$ for $48 \mathrm{~h}$ were analyzed using sq-PCR. Statistically, a significant increase in Bax and $p 53$ expression levels was observed over 2 and 1.5-fold, respectively, compared with the control (Figure 6). Additionally, a dramatic inhibition in the $B c l-2$ mRNA expression level was recorded by a 2 -fold decrease compared with untreated cells (Figure 6). Moreover, $\mathrm{Bax} / \mathrm{Bcl}-2$ ratio was calculated, and the results showed a significant increase in treated HepG2 cells by 4 -fold compared to the untreated group (Figure 6). From this point of findings, ADX can act as an up-regulator for Bax and $p 53$ genes and down regulator for the $\mathrm{Bcl}-2$ gene, and as a result, the ADX can induce apoptosis in treated HepG2 cancer cells.

Khan et al. ${ }^{30}$ stated that apoptotic cell death is indicated in MCF-7 breast cancer cells treated with MEAD by substantial increases in $p 53$, $\mathrm{Bax}, \mathrm{Fas}$, and FasL genes expression and a significant decrease in $\mathrm{Bcl}$ 2 gene expression level as compared to the control group. The fold increase of $p 53$ and Bax was ten-fold when cells exposed to $20 \mathrm{mg} / \mathrm{ml}$ of MEAD for $48 \mathrm{~h}$, which is confirmed the present findings. Siddiqui et al. ${ }^{34}$ reported a downregulation in the expression level of $p 53$ gene in HepG2 cells treated with 15 and $25 \mathrm{mg} / \mathrm{ml}$ ADP for $48 \mathrm{~h}$, compared to untreated cells, which is slightly different from Khan et al. ${ }^{30}$ finding and the current study result. The transcriptional regulation of various processes, such as the cell cycle, apoptosis, and DNA repair, is caused by the stabilization and accumulation of $p 53 .{ }^{62}$ Pro-apoptotic genes, including $B a x$, are upregulated during apoptosis, whereas $B c l-2$ family genes are downregulated. ${ }^{34}$

Additionally, P53 upregulation can modulate transcriptional activation of other associated pro-apoptotic genes. Further supporting the theory that a p53-dependent mechanism can trigger HepG2 cell apoptosis is the increased expression of Bax and p53 genes observed in our research. A drop in $\mathrm{Bcl}-2$ expression and a four-fold increase in Bax/ $B c l-2$ transcription ratio relative to control group expression (Figure 7 ) indicates that $p 53$-mediated signaling triggers HepG2 cell death following treatment ADX, leading to apoptosis.

The Bax/Bcl-2 ratio increased dramaticlly by 4 -fold compared to the control cells, reflecting the increase in apoptosis gene (Bax) transcription level and the decrease in anti-apoptosis gene $(B c l-2)$ mRNA expression level.

Previous studies ${ }^{29,47}$ confirmed the hepatoprotective and antioxidant properties of aqueous and 50\% aqueous acetone ADX in vitro and in vivo. Other investigations $\mathrm{s}^{30,33,34}$ demonstrated the action of methanolic, ethyl acetate, and ethanolic fractions of ADX on different types of human cancer cells through various experimental methods. The impact of ADX was recorded to be associated with ROS induction, mitochondrial membrane potential (MMP) disruption and, DNA damage which causing cell cycle arrest at any phase (G1, S, and G2/M phases) and finally terminated with apoptosis via a $p 53$-dependent ${ }^{30}$ or independent ${ }^{34}$ pathways.

\section{CONCLUSION}

In conclusion, ADX extract investigated in the present study showed anticancer effects decreased the proliferation and viability of HepG2 cancer cells and increased their DNA fragmentation. ADX also upregulated the expression of pro-apoptosis genes, such as p53 and $B a x$, and downregulated the expression of anti-apoptosis genes, such as $B c l-2$. The results of this work are of significant interest because they shed light on the phytochemical components of ADX that render it a natural anticancer agent.

\section{ACKNOWLEDGEMENTS}

The author is gratfull to Taif University, Taif, Saudi Arabia.

\section{ABBREVIATIONS}

ADX: Ajwa date extract; HCC: Hepatocellular carcinoma; HCV: Hepatitis C virus; ADP: Ajwa date pulp; GAPDH: Glyceraldehyde 3-phosphate dehydrogenase; GA: Gallic acid; NG: Naringenin; DOX: Doxorubicin.

\section{REFERENCES}

1. Petrick, J.L., Kelly, S.P., Altekruse, S.F., McGlynn, K.A., Rosenberg, P.S. Future of Hepatocellular Carcinoma Incidence in the United States Forecast Through 2030. J Clin Oncol 2016;34(15);17871794. doi: $10.1200 / J C O .2015 .64 .7412$.

2. Bray, F., Ferlay, J., Soerjomataram, I., Siegel, R.L., Torre, L.A., Jemal, A. Global cancer statistics 2018: GLOBOCAN estimates of incidence and mortality worldwide for 36 cancers in 185 countries. CA Cancer J Clin 2018;68(6):394-424. doi: 10.3322/caac.21492.

3. Tunissiolli, N.M., Castanhole-Nunes, M., Biselli-Chicote, P.M., Pavarino, E.C., da Silva, R. F., da Silva, R.C. Hepatocellular Carcinoma: a Comprehensive Review of Biomarkers, Clinical Aspects, and Therapy. Asi Paci j canc preven 2017;18(4):863-872. doi: 10.22034/APJCP.2017.18.4.863.

4. Jemal, A., Bray, F., Center, M., Ferlay, J., Ward, E., Forman, D Global cancer statistics. CA Cancer J Clin 2011;61:69-90. doi: 10.3322/caac.20107.

5. Yang, J.D. Hainaut, P. Gores, G.J. Amadou, A. Plymoth, A. Roberts, L.R. A global view of hepatocellular carcinoma: trends, risk, prevention and management. Nat Rev Gastroenterol Hepatol 2019;10:589-604.

6. Yatsuji, S., Hashimoto, E., Tobari, M., Taniai, M., Tokushige, K., Shiratori, K. Clinical features and outcomes of cirrhosis due to non-alcoholic steatohepatitis compared with cirrhosis caused by chronic hepatitis. C. J Gastroenterol Hepatol 2009;24:248-254. doi: 10.1038/s41575-019-0186-y.

7. Rasool, M. Rashid, S. Arooj, M. Ansari, S.A. Khan, K.M. Malik, A. et al. New possibilities in hepatocellular carcinoma treatment. Anticancer Res 2014;34(4):1563-71. PMID: 24692683.

8. Hong, M. Li, S., Tan, H.Y., Wang, N., Tsao, S.W., Feng, Y. Current Status of Herbal Medicines in Chronic Liver Disease Therapy: The Biological Effects, Molecular Targets and Future Prospects. Int J Mol Sci 2015;16(12):28705-28745. doi: 10.3390/ijms161226126.

9. Wege, H. Li, J., Ittrich, H. Treatment Lines in Hepatocellular Carcinoma. Visc. Med 2019;35:266-272. . https://doi. org/10.1159/000501749

10. Cragg, G.M., Newman, D.J. Plants as a source of anti-cancer agents. J Ethnopharmacol 2005;100(1-2):72-79. doi: 10.1016/j. jep.2005.05.011.

11. Chahar, M.K., Sharma, N., Dobhal, M.P., Joshi, Y.C. Flavonoids: A versatile source of anticancer drugs. Pharmacogn Rev 2011;9:1-12. doi: 10.4103/0973-7847.79093.

12. Wu, X.Z., Xie, G.R. Induced differentiation of hepatocellular carcinoma by natural products. Afr J Tradit Complement Altern Med 2009;5(4):325-331. PMID: 20161953; PMCID: PMC2816580.

13. Middleton, E.Jr., Kandaswami, C., Theoharides, T.C. The effects of plant flavonoids on mammalian cells: implications for inflammation, heart disease, and cancer. Pharmacol Rev 2000;52(4):673-751. PMID: 11121513.

14. Khader, M., Eckl, P.M. Thymoquinone: an emerging natural drug with a wide range of medical applications. Iran j bas medic scie 2014;17(12):950-957. PMID: 25859298. 
15. El-Mahdy, M.A., Zhu, Q., Wang, Q.E., Wani, G., Wani, A.A. Thymoquinone induces apoptosis through activation of caspase-8 and mitochondrial events in p53-null myeloblastic leukemia HL-60 cells. Int J Cancer 2005;117(3):409-417. doi: 10.1002/ijc.21205.

16. Desai, A.G., Qazi, G. N., Ganju, R. K., El-Tamer, M., Singh, J., Saxena, A.K. et. al. Medicinal plants and cancer chemoprevention. Curr Drug Metab 2008;9(7):581-591. doi: 10.2174/138920008785821657.

17. Baliga, M.S., Baliga, B.R.V., Kandathil, S.M., Bhat, H.P., Vayalil, P.K. A review of the chemistry and pharmacology of the date fruits (Phoenix dactylifera L.). Food Res Int 2001;44(7):1812-22. https:// doi.org/10.1016/j.foodres.2010.07.004

18. Saafi, E.B., Louedi, M., Elfeki, A., Zakhama, A., Najjar, M.F., Hammami, M., et. al. Protective effect of date palm fruit extract (Phoenix dactlifera L) on dimethoate induced-oxidative stress in rat liver. Exp ToxicolPathol 2011;63(5):433-41. doi: 10.1016/j. etp.2010.03.002.

19. Aisha, A. F.A., Nassar, Z.D., Siddique, M.J., Abu-Salah, K.M., Alrokayan, S.A., Ismail, Z. et. al. Evaluation of antiangiogenic, cytotoxic and antioxidant effects of SyzgiumaromaticumL.extracts. Asian J Biol Sci 2011;4(3):282-290. PMID: 22186303.

20. Shahadi, F., Naczk, M. Phenolics in Food and Nutraceuticals., $2^{\text {nd }}$ edi. CRC Press LLC; 2019

21. Hasan, N.S. Amon, Z.H. Nor, A.I. Mokhtarrudin, N. Esa, N.M., Azlan, A. Nutritionalcomposition and in vitro evaluation of the antioxidants propertiest of various dates extracts (Phoenix dactylifera L.) from Libya. Asian J Clin Nutr 2010;2(4):208-214. doi: 10.3923/ ajcn.2010.208.214

22. Al-Shahib, W., Marshall ,R.J. The fruit of date palm: Its possible use as thebest food for the future? Int J Food Sci Nutr 2003;54(4):24759. doi: 10.1080/09637480120091982

23. Ali, A., Abdu, S. Antioxidant protection against pathological mycotoxins alterations on proximal tubules in rat kidney. Func Foods Health Dis 2011;1(4):118-34. doi:10.3923/krj.2011.13.23

24. Zhang, C.R., Aldosari, S.A., Vidyasagar, P.S., Nair, K.M., Nair, M.G. Antioxidant and anti-inflammatory assays confirm bioactive compounds in Ajwa Date fruit. J. agricult. food chem 2013;61 (24):5834-40. doi: 10.1021/jf401371v

25. Sheikh, B.Y., Elsaed, W.M., Samman, A.H., Sheikh, B.Y., Ladin A-M, M.B. Ajwa dates as a protective agent against liver toxicity in rat. Eur Scient J 2014;3:358-368. . https://doi.org/10.19044/ esj.2014.v10n7p\%p

26. Imran, I., Butt, I.M., Ul-hassan, Z., Iqbal, S. Ameliorative Effect of Phoenix Dactylifera(Ajwa) On Renal Biochemical Markers In Alloxan Induced Diabetic Nephropathic Rats., Indo Am. J. P. Sci 2019;6(2):4313-4320.

27. Khalid, S., Ahmad, A., Kaleem, M. Antioxidant Activity and Phenolic Contents of Ajwa Date and Their Effect on Lipo-Protein Profile. Ffhd 2017;7(6):396-410. doi: : 10.31989/ffhd.v7i6.337

28. Eid, N., Enani, S., Walton, G., Corona, G., Costabile, A., Gibson, G. et. al. The impact of date palm fruits and their component polyphenols, on gut microbial ecology, bacterial metabolites and colon cancer cell proliferation. J nutri scie 2014;3:e46. doi: 10.1017/jns.2014.16.

29. Al-Radadi, N. S. Green synthesis of platinum nanoparticles using Saudi's Dates extract and their usage on the cancer cell treatment. Arab. J Chemis 2019;12(3):330-349. https://doi.org/10.1016/j. arabjc.2018.05.008

30. Ishurd, O., Zgheel, F., Kermagi, A., Flefla, M., Elmabruk, M. Antitumor activity of $\beta$-d-glucan from Libyan dates. J Med Food 2004;7(2):252-255. doi: 10.1089/1096620041224085.

31. Khan, F., Ahmed, F., Pushparaj, P.N., Abuzenadah, A., Kumosani, T., Barbour, E. et. al. Ajwa Date (Phoenix dactylifera L.) Extract Inhibits Human Breast Adenocarcinoma (MCF7) Cells In Vitro by Inducing Apoptosis and Cell Cycle Arrest. PloS one 2016;11(7):e0158963. doi: 10.1371/journal.pone.0158963.
32. Khan, F., Khan, T.J., Kalamegam, G., Pushparaj, P.N., Chaudhary, A., Abuzenadah, A. et. al. Anticancer effects of Ajwa dates (Phoenix dactylifera L.) in diethylnitrosamine induced hepatocellular carcinoma in Wistar rats. BMC complemen altern medi 2017;17(1):418. doi: 10.1186/s12906-017-1926-6.

33. Mirza, M.B., Elkady, A.I, Al-Attar, A.M., Syed, F.Q., Mohammed, F.A., Hakeem KR. Induction of apoptosis and cell cycle arrest by ethyl acetate fraction of Phoenix dactylifera L. (Ajwa dates) in prostate cancer cells. J. Ethnopharmacol 2018;218:35-44. doi: 10.1016/j.jep.2018.02.030.

34. Siddiqui, S., Ahmad, R., Khan, M.A., Upadhyay, S., Husain, I., Srivastava, A.N. Cytostatic and Antitumor Potential of Ajwa Date Pulp against Human Hepatocellular Carcinoma HepG2 Cells. Sci Rep. 2019;9:245. https://doi.org/10.1038/s41598-018-36475-0

35. Al-Jaouni, S., Abdul-Hady, S., El-Bassossy, H., Salah, N., Hagras, M. Ajwa Nanopreparation Prevents DoxorubicinAssociated Cardiac Dysfunction: Effect on Cardiac Ischemia and Antioxidant Capacity. Integ. cancer ther 2019;18:1-9. doi: 10.1177/1534735419862351.

36. Strober, W. Trypan blue exclusion test of cell viability. Curr Protoc Immunol 2001;Appendix 3:Appendix 3B. doi: 10.1002/0471142735. ima03bs21.

37. Horiuchi, N., Nakagava, K., Sasaki, Y., Minato, K., Fujiwara, Y., Nezu, K. et. al. In vitro antitumor activity of mitomycin $C$ derivative (RM- 49) and a new anticancer antibiotic (FK973) against lung cancer cell lines determined by tetrazolium dye (MTT) assay. Cancer Chemother Pharmacol 1998;22(3):246-50. doi: 10.1007/ BF00273419.

38. Bortner, C., Nicklas, B.E., Oldenburg, J., Cidlowski, A. The role of DNA fragmentation in apoptosis. Trends Cell Biol 1995;5(1):21-26. doi: 10.1016/s0962-8924(00)88932-1.

39. Burton, K. A study of the conditions and mechanism of the diphenylamine reaction for the colorimetric estimation of deoxyribonucleic acid. Biochem J 1965;62(2):315-323. doi: 10.1042/ bj0620315.

40. Perandones, C.E. Illera, V.A., Peckham, D., Stunz, L.L., Ashman, R.F. Regulation of apoptosis in vitro in mature murine spleen $T$ cells. J Immunol 1993;151(7):3521-3529. PMID: 8376790

41. Brun, M.E., Gasca, S., Girard, C., Bouton, K., De Massy, B., De Sario, A. Characterization and expression analysis during embryo development of the mouse ortholog of MLL3, Gene. 2006;371(1): 25-33.

42. Hassan A. M., Abdel-Aziem S. H., Abdel-Wahhab, M.A. Modulation of DNA damage and alteration of gene expression during aflatoxicosis via dietary supplementation of Spirulina (Arthrospira) and whey protein concentrate. Ecotoxicol environ saf. 2012;79:294300. doi: 10.1016/j.ecoenv.2012.01.017.

43. Kazemi N., Beigi Shahrestani S. Effect of Saffron Extract on Expression of Bax and Bcl-2 Genes in Gastric Adenocarcinoma Cell Line (AGS), Gene Cell Tissue. 2018;5(3):e63608. . doi: 10.5812/ gct.63608

44. Liu H., Zhou, M. Evaluation of p53 gene expression and prognosis characteristics in uveal melanoma cases. Onco Targets Ther. 2017;10:3429-3434. https://doi.org/10.2147/OTT.S136785.

45. Waller, R.A., Duncan, D.B. A Bayes rule for the symmetric multiple comparisons problem. J. Americ Statistic Associ 1969;64(328):1484-1503. https://doi.org/10.2307/2286085.

46. Senedecor, G.W., Cochran, W.G. Statistical methods. $7^{\text {th }}$ ed., lowa State University Press, Ames; 1980

47. Nematallah, K. A., Ayoub, N. A., Abdelsattar, E., Meselhy, M. R., Elmazar, M. M., ElKhatib A, H., et. al. Polyphenols LC-MS2 profile of Ajwa date fruit (Phoenix dactylifera L.) and their microemulsion: Potential impact on hepatic fibrosis. J funct foods 2018;49:401-411. https://doi.org/10.1016/j.jff.2018.08.032. 
48. Sourani, Z., Pourgheysari, B., Beshkar, P., Shirzad, H., Shirzad, M. Gallic Acid Inhibits Proliferation and Induces Apoptosis in Lymphoblastic Leukemia Cell Line (C121). Iran J med scie 2016;41(6):525-530. PMC5106568.

49. Aborehab, N.M., Osama, N. Effect of Gallic acid in potentiating chemotherapeutic effect of Paclitaxel in HeLa cervical cancer cells. Cancer Cell Int 2019;19:154. doi: 10.1186/s12935-019-0868-0.

50. Du, G.J., Zhang, Z., Wen, X.D., Yu, C., Calway, T., Yuan, C.S. et. al. Epigallocatechin Gallate (EGCG) is the most effective cancer chemopreventive polyphenol in green tea. Nutrients 2012;4(11):1679-1691. doi: 10.3390/nu4111679.

51. Subramanian, A.P., John, A.A., Vellayappan, M.V., Balaji, A., Jaganathan, S.K., Supriyanto, Eko. et. al. Gallic acid: prospects and molecular mechanisms of its anticancer activity. RSC Adv 2015;5(45):35608- 35621. doi:10.1039/C5RA02727F

52. Taubert, D., Berkels, R., Roesen, R., Klaus, W. Chocolate and blood pressure in elderly individuals with isolated systolic hypertension. JAMA 2003;290(8):1029-30. doi: 10.1001/jama.290.8.1029.

53. Huang, W.Y., Cai, Y.Z., Zhang, Y. Natural phenolic compounds from medicinal herbs and dietary plants: potential use for cancer prevention. Nutr Cancer 2009;62(1):1-20. doi: 10.1080/01635580903191585.

54. Stanisavljević, N.S., Ilić, M.D., Matić, I.Z., Jovanović, Ž.S., Čupić, T., Dabić, D.Č. et. al. Identification of Phenolic Compounds from Seed Coats of Differently Colored European Varieties of Pea (Pisum sativum L.) and Characterization of Their Antioxidant and In Vitro Anticancer Activities. Nutr cancer 2016;68(6):988-1000. doi: 10.1080/01635581.2016.1190019.
55. Godugu, K., El-Far, A.H., Al Jaouni, S., Mousa, S.A. Nanoformulated Ajwa (Phoenix Dactylifera L.) Bioactive Compounds Improve the Safety of Doxorubicin without Compromising its Anticancer Efficacy in Breast Cancer. Molecules 2020;25(11):2597. doi: 10.3390/ molecules25112597.

56. Kaliora, A.C., kanellos, P.T., Kalogeropouls, N. Gallic acid bioavailability in humans, in:Thompson, M. A., and Collins, P., B., Handbook on gallic acid, Nova publishers Inc, pp. 301-312.

57. Kocyigit, A., Koyuncu, I., Dikilitas, M., Bahadori, F., Turkkan, B. Cytotoxic, genotoxic and apoptotic effects of naringenin-oxime relative to naringenin on normal and cancer cell lines. Asi Paci J Tropi Biomed 2016;6(10). https://doi.org/10.1016/j.apjtb.2016.08.004.

58. Jaganathan, S.K., Mandal, M. Involvement of non-protein thiols, mitochondrial dysfunction, reactive oxygen species and p53 in honey-induced apoptosis. Investig. N. Drugs 2010;28(5):624-33. doi: 10.1007/s10637-009-9302-

59. Phillips, P., Sangwan, V., Borja-Cacho, D., Dudeja, V., Vickers, S., Saluja, A. Myricetin induces pancreatic cancer cell death via the induction of apoptosis and inhibition of the phosphatidylinositol 3-kinase (PI3K) signaling pathway. Cancer Lett 2011;308(2):181188. doi: 10.1016/j.canlet.2011.05.002

60. Abed El-Azim, M.H.M., El-Mesalamy, A.M.D., Yassin, F.A., Khalil, S.A. Identification Phenolic and Biological Activities of Methanolic Extract of Date Palm Pollen (Phoenix dactylifera). J MicrobBiochem Technol 2015;7(1):47-50. doi:10.4172/1948-5948.1000180.

61. Taatjes, D.J., Sobel, B.E., Budd, R.C. Morphological and cytochemical determination of cell death by apoptosis. Histochem cell biol 2008;129(1):33-43. doi: 10.1007/s00418-007-0356-9.

62. Chipuk, J., Green, D. (2006). Dissecting p53-dependent apoptosis. Cell Death Differ 2006;13(6):994-1002. doi: 10.1038/ sj.cdd.4401908.

\section{ABOUT AUTHORS}

Dr.Faizah Ahmed AlMalki, got master's degree in molecular genetics from King Abdulaziz University at Jeddah, Kingdom od Saudi Arabia and a PhD from University of Sheffield, UK, in macromolecular complexes using crystallography techniques. Currently working in Biology department, faculty of science, Taif University, KSA. My research is focuses on using alternative therapy of cancer from bioactive natural products and green synthesis of functionalized nanoparticles and their biological activities.

Cite this article: Almalki FA. Cytotoxic Activities of Phytochemical Components from Ethanol Extract of Ajwa Date on Human Hepatoma Cancer Cells in Vitro. Pharmacogn J. 2021;13(6)Suppl: 1664-1672. 